\title{
Alessandro Malaspina: An Italian-Spaniard at Port Jackson
}

\author{
LAURA OLCELLI
}

$\mathrm{B}$ etween 1789 and 1794, Tuscan-born, Sicilian-raised, Romaneducated and Spanish-trained Alessandro Malaspina (Mulazzo, 1754-Pontremoli, 1810) captained the most important scientific expedition ever undertaken by Spain, a feat which earned him the appellation Mercedes Palau gave him of 'a Spaniard in Italy and an Italian in Spain'. ${ }^{1}$ In this article I will focus on Malaspina's already ambivalent status as both Italian and Spanish, and I will relate it to the New South Wales leg of his Pacific expedition and voyage account. I will draw on Viaje politico-cientifico alrededor del mundo (the 1885 original Spanish reportage) and Journal of the Voyage by Alejandro Malaspina (its 2001-2004 English translation), and supplement these texts with the captain's secret reports, which were published in 1990 in English by Robert King. Firstly, I will analyse Malaspina's comments that informed a Spanish audience about the infant colony and its Aboriginal 
inhabitants, and contrast them to privileged 'originary' British descriptions. Subsequently, I will demonstrate how, by including quotations from Italian literature, the Port Jackson leg of Malaspina's journal gives voice to his 'Italianness', which, up to this point, had been suppressed by his official identification with Spanish interests. ${ }^{2}$

After the submission, on 10 September 1788, of a 'Plan for a Scientific and Political Voyage Around the World' to the Spanish Minister of the Marine, Antonio Valdés y Bazán, two identical vessels were built specifically for the expedition. The Descubierta (Discovery) would be captained by Malaspina, and the Atrevida (Daring) by José de Bustamante y Guerra. However, as Donald Cutter observes:

At some indeterminate time, the concept of dual command gave way to the enterprise being called the Malaspina expedition rather than the MalaspinaBustamante voyage... perhaps because Malaspina was the elder of the two commanding officers. Malaspina was also the more vocal and motivated leader, though each continued to command his own corvette. ${ }^{3}$

Although the Malaspina expedition was chiefly understood to be a scientific expedition, it also had clear political objectives, especially in connection to New South Wales. In a letter dated 24 April 1789, Malaspina wrote to Valdés:

[I]t is important to decide on... whether New Holland and New Zealand are to be looked at with political rather than naturalists' eyes, that is to say whether from the study of various parts of those vast regions solidly-based conclusions with relation to particular products can be developed beyond the few recently established in those areas. $^{4}$

The principal reason for Malaspina's visit to Port Jackson was Spain's thwarted imperial ambitions regarding the territory now claimed for Britain. The Spanish authorities were concerned about the potential economic and strategic impact of the establishment of a British settlement in New South Wales on Spanish Pacific interests and sent Malaspina to inspect its advancement.

The two corvettes departed on 30 July 1789. After the Atlantic crossing from Cadiz to Montevideo, they rounded Cape Horn, sailing up the coast of South and Central America as far as Acapulco, where they 
received orders to head north. They therefore surveyed the northwestern coast of America and unsuccessfully tried to detect the Northwest Passage. ${ }^{5}$ Then, they directed their course towards the South Pacific, via the Sandwich Islands (Hawai'i) and the Philippines. In the proposed route, they were expected to hug New Holland (Australia) and anchor, consecutively, at Port Jackson, Tonga, the Society Islands and New Zealand. However, because of unfavourable weather conditions, they actually travelled from Manila to New Zealand's South Island (passing by New Guinea, the Solomon Islands, the New Hebrides and New Caledonia) and only subsequently to New South Wales, New Zealand's North Island and Tonga.

On 13 March 1793 the Descubierta approached New South Wales and on the evening of the 13 the Atrevida joined it. This would be their harbour for one month, where their crew would re-stock the ships, botanize, carry out gravity experiments and rest before continuing to New Zealand. Malaspina's comments in his Journal of the Voyage by Alejandro Malaspina reflect, on many levels, the British colonial power in the infant colony. For instance, he uses the names given by and in honour of the British scientists on the Endeavour expedition ('we could easily make out Banks and Solander Points'); he sees not only huts and naked natives, but also a British flag - '[w]e then hoisted our ensigns and soon saw a flag flying from a small hill between Port Jackson and Botany Bay' - and then he writes: 'we were able to receive on board an English pilot who came out to meet us'. The British 'discovered' the east coast of Terra Australis; the Spanish found a British colony. ${ }^{6}$

The Spanish were not only visiting what had become a British settlement, but also re-visiting the British writings on the area.

Malaspina was certainly familiar with other European logs, and a British linguistic-stylistic trace can be found in his narrative. For example, his depiction of Port Jackson echoes previous British ones. James Cook observed 'a Bay or Harbour wherein appeared to be safe anchorage', 7 and Governor Arthur Phillip 'had the satisfaction to find one of the finest harbours in the world, in which a thousand sail of the line might ride in perfect security'. ${ }^{8}$ Malaspina's description fuses Cook's practicality and Phillip's enchantment: 'It is impossible to describe the beauty of the harbour and the admiration it must arouse in every sailor who enters it. Nature has contrived to do everything possible to make it both pleasant and safe ${ }^{\prime}{ }^{9}$ Malaspina's account achieves a poetic style as he registers the impossibility of verbalizing what he sees. The contrast between 'impossible' and 'everything possible' is in the English translation only; in Spanish we read 'No cabe una descripción adecuada' - 'There is no adequate description' - and 'La naturaleza ha ocurrido á cuanto podía 
hacerle igualmente cómodo y seguro' - 'Nature has contrived to do everything possible to make it both pleasant and safe ${ }^{\prime 10}$ In both languages, however, the lines confer a feeling of the sublime. The primacy of the British discoveries is reflected in the originality of their travel journals; the Spanish counterpart exposes, instead, their secondhand findings and imitative writing approach.

Soon after his stay, Malaspina also compiled two reports. One is 'A Political Examination of the English Colonies in the Pacific', and the other 'Loose Notes on the English Colony of Port Jackson'. ${ }^{11}$ Particularly in the first document, Malaspina displays a harsh attitude towards Britain. After justifying himself as a reporter in the name of Spain, he unreservedly denounces the blind ambition of the British and their abuse of power in New South Wales:

[T]he transportation of the convicts constituted the means and not the object of the enterprise. The extension of Dominion, mercantile speculations, and the discovery of Mines were the real object; and to these, albeit vain, hopes, were sacrificed the restraints of Legislation, the principles of sane policy, and above all the compassionate cries of oppressed Humanity. ${ }^{12}$

In the official account, Malaspina illustrates the all-encompassing supremacy and influence of the British; in his secret notes, he exposes the insidiousness of their domination. Either way, he confirms that Spain has to concede the consolidated presence of Britain in that part of the Pacific.

It is particularly significant that Malaspina does not make any ethnographical comments on Australian Aborigines in his journal. He simply orders that ' $[t]$ here should be an armed sergeant or constable in the pinnace employed in fishing to prevent any surprise by the natives, a not unlikely occurrence, from what we had been told in the colony'. Instead, the journalist shifts his comments from the Indigenous Australian inhabitants to the recently arrived British ones: both convicts and colonists. Where natives were generally allowed restricted access aboard the ships, now '[n]o convict should be allowed on board the pinnaces or the corvettes'. Moreover, as an example of his poor opinion of the penal population, Malaspina refers to 'continuous seductions by the female convicts, who seemed drawn to the men more out of lust than interest and whose behaviour was so licentious that, in comparison, the women of Tenerife, as portrayed by Mr White in his Journal, would appear chaste'. ${ }^{13}$ 
I would not classify Malaspina's attitude as misanthropic or racist. As his biographer Dario Manfredi claims, 'Man... remains at the first place in the interest of Malaspina', ${ }^{14}$ and observations about linguistic, cultural and psychological aspects of native populations are present elsewhere in his account. Rather, I would perceive his failure in firsthand encounter as a further indication, on the ethnographic level, of the British impact in New South Wales. As Henry Reynolds explains, with the development of the penal colony, Aboriginal people were killed whenever they presented an obstacle and were decimated by European diseases. ${ }^{15}$ According to Alan Moorehead, the Aboriginal population living around Port Jackson declined from 1500 in 1788 to a few hundred in the 1830 s. ${ }^{16}$ By 1793 , the decreasing number of the Australian natives may have limited Malaspina's capacity to include ethnographic comments on them in his journal. Denigrating descriptions often reserved in European accounts for Indigenous peoples are here reserved for British prisoners.

Furthermore, although in his secret reports about Port Jackson Malaspina does allow room for Aboriginal people, their descriptions echo previous British ones, and their presence is judged in the novel British context. In the 'Political Examination', the few autochthonous inhabitants are not represented as a menace to the expansion of the British; on the contrary, he foresees a 'fatal impact': '[I]t would be better for the English to remove them from these parts, than make them useful for future mutual Prosperity;... what will be easier and sooner will be the destruction rather than the civilization of these unhappy people ${ }^{\prime 17}$ His comment - 'The Negritos of New Holland described by Captain Cook are the most miserable and least advanced nation which exists on earth' $-{ }^{18}$ is highly reminiscent of William Dampier's negativity about northwest natives: 'The inhabitants of this Country are the miserablest People in the world'. ${ }^{19}$ Similarly, Malaspina's comment that '[i]n spite of their simplicity they live happily ${ }^{20}$ parallels Cook's that 'the Natives of NewHolland... may appear to some to be the most wretched people upon Earth, but in reality they are far more happier than we Europeans ${ }^{\prime 21}$ Finally, Malaspina admits he has infrequent contacts with the natives, and that his insights might be misunderstandings and should therefore be verified with earlier ones - 'exposed always to the errors of... confusing the Indigenous customs with those which have been imperfectly adapted from the Europeans'; 'we scorn whatever has not been compared'. ${ }^{22}$ The Spanish chiefly got to know the Australian Aborigines through the British reports: they have an indirect, 'recycled' form of knowledge. 
In general, the 'substitution' of the Aborigine with the British colonial subjects is explicit in further ways in Malaspina's account. His human relationships are all with figures of British colonial authority, particularly Major Francis Grose, the governor who succeeded Phillip. Malaspina was determined to maintain 'a friendly relationship' with his hosts, and similarly receives the kindest of the welcomes. ${ }^{23}$ In the infant colony, communication now means being acquainted with the English rather than the native language. A repetition of the same misunderstandings as occurred between Englishmen and Australian Aborigines is said to have been prevented by the knowledge of English of Atrevida midshipman Don Jacobo Murphy. Furthermore, the early intercultural exchanges between the British and Aboriginal people had been transformed into intra-European gift-exchanges. For example, Malaspina remembers:

[W] e were able to serve chocolate and buñuelos and, in preference to anything else, other samples of Spanish food. Similar invitations and civilities were exchanged amongst equivalent ranks, and thus the warmth of our friendship grew to a close bond clearly indicative of a mutual sympathy with good breeding between our two nations. ${ }^{24}$

Also, before departing, 'Major Grose accepted with pleasure two views of the port, and one of Parramatta drawn by the masterly hand of Don Fernando Brambila and capable of providing England with a clear idea of the present state of that colony'. Finally, the artists, in addition to drawing the natives, painted miniatures of 'the ladies and gentlemen of the colony who wanted to remind their friends and relatives in England of the vast distances which separated them' ${ }^{\prime 25}$ Thus, in a way that reflects the British colonists' expropriation of Aboriginal land, they also won increasing space over the Indigenous inhabitants in travel accounts of post-settlement Australia.

The Australian leg of Malaspina's journal is essentially a commentary on British colonialism in New South Wales in the early 1793. His pioneering visit verifies the progress of the penal settlement, emphasising the defeat of Spain in that part of the Spanish Lake. As Cutter suggests: 'Although Malaspina in his visit there fulfilled his orders to learn as much as possible about the new British colony, he also realised that Spain no longer had even a remote chance of claiming the area or of dislodging any non-Spanish settlements' ${ }^{26}$ 
The gifting of Spanish food and pictures allows me to introduce another subject, namely the presence of Spanish references in the diary, which serve to qualify the diarist as a representative of Spain. In the introduction Malaspina had already declared: '[I]f I could fulfil... the obligations which arise from my intense and inextinguishable gratitude to the Monarch who has honoured me and to the nation that has taken me as one of its own!'. ${ }^{27}$ This statement is followed by numerous references to His Majesty the Spanish king, whose generosity Malaspina is determined to reward, and whose instructions he strictly intends to follow. In the New South Wales leg, there are two particularly noteworthy examples. Having offered a meal to the British aboard the Descubierta, Malaspina gives details of their toasts:

[T] he first to the King of England, the King of Spain and both Royal Families; the second to Commodore Phillip, Major Grose, and the prosperity of the colony; and the third to the ladies who favoured us with their presence. As was to be expected, all our guests repeated the toast naming the King of Spain before the King of England. The crew echoed these sentiments of affection and respect with their 'Long live the King' while the regimental band played the anthem 'God Save the King', which lent all appropriate dignity to this pleasant and affectionate scene. ${ }^{28}$

This sign of patriotism - Malaspina being pleased that the British officers gave preference to the Spanish king in their toasts - is followed by a touch of Spanish pride. He wrote:

The endeavours and hopes of the community were further encouraged by the success of their fruit trees, vegetables, and above all lemons and vines. Finally, this same area offered a healthy climate and abundant pastures for the herds of cattle, sheep and horses. Their first offspring, although very few in number, fostered the pleasant prospect that this new centre of national opulence would soon see English activity and administration combined with the climate and soil typical of our Andalusia. ${ }^{29}$

Malaspina commented on the great progress brought about by the British in the colony, but at the same time admitted the natural advantages of New South Wales, and compares these to the healthy 
weather and abundant meadows of southern Spain. ${ }^{30}$ The impression is that, whenever possible, Malaspina mentions and praises Spain and its king. More specifically, at Port Jackson, by perceiving and including a Spanish equivalent for everything British with which he comes in contact, he reveals his Spanishness. He 'exists' exclusively thanks to a Spanish scientific project, and this explains why, despite being a native Italian, he rather identifies himself with the nation he serves.

Nonetheless, Malaspina's writing also has an Italian literary and personal component. Postponed until the fourth year of navigation, it is exactly at Port Jackson that we encounter the first quotation from Italian literature. " [C]he tutti ascolta, e porge a tutti aita" (Filicaja)' is cited following an expression of appreciation for Chaplain Richard Johnson, who helped Father José de Mesa recover 'with a kindness, spirit of unity and a simplicity that were truly of the Gospel'. This is not a personal tribute to Johnson, but to 'the mysterious decrees of Providence'. The verse is incorrectly spelt 'Che tutti ascolta, e por ge a tutti aita' ${ }^{31}$ in the original 1885 Spanish edition: it signals a possible error on the part of the writer, but the sense remains understandable. A footnote in the 2001 English translation of Malaspina's journal renders it as 'who listens to all and provides help to all' ${ }^{32}$ This is technically correct, but loses the poetical nuance of 'aita', the antique correspondent of the modern Italian word for 'help', aiuto. This verse comes from Opere del senatore Vincenzio da Filicaja (1804), ${ }^{33}$ written by a seventeenth-century Senator of Florence and poet of the Accademia della Crusca. In the first tome of his collection, which includes the Tuscan poems, sonnet 156 is entitled 'Sopra la Divina Provvidenza', on the Divine Providence. Da Filicaja compares a mother's 'compassionate affection' towards her children, to that of Providence towards the faithful. By quoting an illustrious Tuscan poet, Malaspina offers two reminders of his Italian upbringing, referencing both his Tuscan origins and religious Italian education.

Two references from Torquato Tasso's pastoral drama Aminta: favola boschereccia (1573) also follow at the latitude of Vava'u (Tonga). It appears that the writer exploits the medium of the Italian literary quotation to seek familiarity in the exotic, and thus understand it and make it accessible to his informed readers. In this way, he displays his cultural capital, and brings his Italian roots to light. Frederic Regard recognizes that 'all narratives of first encounters were written at this juncture between an inherited national "culture" ... and a revolutionary cognitive or hermeneutic event demanding personal adaptation to the new situation' ${ }^{34}$ In addition to Regard's argument, Sandhya Patel maintains that ' $[t]$ he writing of travel and its publication has served 
various ideological ends over the centuries. Prominent among those is the production of a newly discovered Other, both place and person, but also of a rediscovered Self, that of the traveller himself' ${ }^{35}$ It seems that Malaspina's 'found again self' is his Italian background and his selfunderstanding as Italian. ${ }^{36}$ Until now, in antithesis with his biography, it had been suppressed by the Spanish duty, and only through his writing he is able to revive it.

Nowadays, Tuscan Malaspina is better known as the captain of Spain's most important scientific expedition. His allegiance to Spain and the nature of his journal, originally compiled in Spanish, have long since sealed his presence in Spanish historiography. However, the analysis of Malaspina's record of the expedition's Port Jackson leg discloses how his references to Spain and King Charles IV are balanced by quotations from Italian literature, which cast new light on his enduring 'Italianness'. Just as, in the collective imagination, he is 'a Spaniard in Italy and an Italian in Spain', in embryonic Sydney we glimpse a Tuscan soul behind the guise of Spanish duty.

Laura Olcelli is a doctoral candidate in the Department of English at the University of Sydney

\section{ENDNOTES}

${ }^{1}$ Mercedes Palau, 'Alejandro Malaspina and His Vision of Colonial America', in Robin Inglis (ed), Spain and the NorthWest Coast, Essays from a symposium, Vancouver Maritime Museum, Vancouver, 1992, in John Kendrick, Alejandro Malaspina: Portrait of a Visionary, McGill-Queen's University Press, Montreal, 1999, p8. Italian in Spain, Spanish in Italy is also the title of Dario Manfredi's book on the Malaspina expedition. Dario Manfredi, Italiano in Spagna, spagnolo in Italia: Alessandro Malaspina (1754-1810) e la più importante spedizione scientifica marittima del Secolo dei Lumi, Nuova Eri Edizione Rai, Turin, 1992. For biographical information on Malaspina, in addition to the above works, see Emma Bona, Alessandro Malaspina: sue navigazioni ed esplorazioni, Istituto grafico tiberino, Rome, 1935, and Donald C. Cutter, 'Malaspina, Alejandro', Dictionary of Canadian Biography Online, http: / / www.biographi.ca/009004-119.01-e.php?\&id_nbr=2526, accessed 21 September 2012. An earlier version of this article was presented at the "From the Ground Up: People and Places in Sydney's Past" conference (State Library of New South Wales, 23-24 August 2012). Thanks to Vanessa Smith for her incommensurable assistance at all stages of writing.

${ }^{2}$ My references to Malaspina as an Italian and his 'Italianness' are to be understood as indicators of his geographical and cultural, but not political connection to the Italian peninsula, since the Kingdom of Italy did not unify until 1861.

${ }^{3}$ Donald C. Cutter, Malaspina \& Galiano: Spanish Voyages to the Northwest Coast, 1791 $\mathcal{E} 1792$, Douglas \& McIntyre, Vancouver, c1991, p4.

4 'Malaspina to Valdés. Cádiz, 24 April 1789', in 'The Malaspina-Valdés Correspondence', in Alejandro Malaspina, The Malaspina Expedition, 1789-1794: Journal of the Voyage by Alejandro Malaspina, 3 vols, edited by Andrew David, Felipe Fernandez-Armesto, Carlos Novi, Glyndwr Williams, introduction by Donald C. Cutter, Hakluyt Society, London, 2001-4, 1:317-18. 
${ }^{5}$ On Malaspina and the Northwest Passage, see Laura Olcelli, 'The denied search for the Northwest Passage: Alessandro Malaspina at the service of "the nation that has taken me as one of its own!"', Terrae Incognitae (forthcoming).

${ }^{6}$ Alejandro Malaspina, The Malaspina Expedition, 1789-1794: Journal of the Voyage by Alejandro Malaspina, 3 vols, edited by Andrew David, Felipe Fernandez-Armesto, Carlos Novi, Glyndwr Williams, introduction by Donald C. Cutter, Hakluyt Society, London, 2001-4, vol 3, pp64; 64; 66. All following references are to this edition.

${ }^{7}$ James Cook, The Journals of Captain James Cook on his Voyages of Discovery. I: The Voyage of the Endeavour, 1768-1771, edited by J. C. Beaglehole, Hakluyt and Cambridge University Press, Cambridge, 1955, p312. Entry for 6 May 1770.

${ }^{8}$ Arthur Phillip, The Voyage of Governor Phillip to Botany Bay, John Stockdale, London, 1798, facsimile reprint of the first edition, Libraries Board of South Australia, Adelaide, 1968, p47. Entry for 18 January 1788.

${ }_{9}$ vol 3, p71.

${ }^{10}$ Alejandro Malaspina, Viaje político-científico alrededor del mundo por las corbetas Descubierta y Atrevida al mando de los capitanes de navio D. Alejandro Malaspina y Don José de Bustamante y Guerra desde 1789 á 1794, publicado con una introducción por Don Pedro de Novo y Colsón, teniente de navío, académico correspondiente de la real de la historia, segunda edición, Imprenta de la viuda e hijos de Abienzo, Madrid, 1885, p253.

${ }^{11}$ This latter report is unsigned but attributed to Malaspina. Robert J. King, The Secret History of the Convict Colony: Alexandro Malaspina's Report on the British Settlement of New South Wales, Allen \& Unwin, Sydney, 1990, p90.

${ }^{12}$ Alexandro Malaspina, 'A Political Examination of the English Colonies in the Pacific', in Robert J. King, The Secret History of the Convict Colony: Alexandro Malaspina's Report on the British Settlement of New South Wales, Allen \& Unwin, Sydney, 1990, p96.

${ }_{13}$ vol 3, pp73; 73; 84. John White was the surgeon on the First Fleet.

${ }^{14}$ Dario Manfredi, Alessandro Malaspina dei Marchesi di Mulazzo: le inclinazioni scientifiche e riformatrici, Istituto internazionale di studi liguri, sezione lunense; Centro aullese di ricerche e di studi lunigianesi, 1984, p53. See also pp51-59. My translation.

${ }^{15}$ On the frontier conflict between European settlers and Australian Aborigines, see the work of Reynolds, for example Henry Reynolds (ed), Aborigines and Settlers: The Australian Experience, 1788-1939, Cassell Australia, North Melburne, 1972, and Henry Reynolds, The Other Side of the Frontier: Aboriginal Resistance to the European Invasion of Australia, Penguin Books, Ringwood, 1982.

${ }^{16}$ Alan Moorehead, The Fatal Impact: An Account of the Invasion of the South Pacific, 1767-1840, Hamish Hamilton, London, 1966, p169.

${ }^{17}$ Alexandro Malaspina, 'A Political Examination of the English Colonies in the Pacific', in Robert J. King, The Secret History of the Convict Colony: Alexandro Malaspina's Report on the British Settlement of New South Wales, Allen \& Unwin, Sydney, 1990, pp105-6.

${ }^{18}$ Alexandro Malaspina, 'A Political Examination of the English Colonies in the Pacific', in Robert J. King, The Secret History of the Convict Colony: Alexandro Malaspina's Report on the British Settlement of New South Wales, Allen \& Unwin, Sydney, 1990, p144.

${ }^{19}$ William Dampier, A New Voyage Round the World, first published 1697, reprinted from the edition of 1729, Adam and Charles Black, London, 1937, pp312-14, in Jan Bassett (ed), Great Southern Landings: An Anthology of Antipodean Travel, Oxford University Press, Melbourne, 1995, p31. This similarity has also been remarked by King. Robert J. King, The Secret History of the Convict Colony: Alexandro Malaspina's Report on the British Settlement of New South Wales, Allen \& Unwin, Sydney, 1990, p84. 
${ }^{20}$ Alexandro Malaspina, 'A Political Examination of the English Colonies in the Pacific', in Robert J. King, The Secret History of the Convict Colony: Alexandro Malaspina's Report on the British Settlement of New South Wales, Allen \& Unwin, Sydney, 1990, p148.

${ }^{21}$ James Cook, The Journals of Captain James Cook on his Voyages of Discovery. I: The Voyage of the Endeavour, 1768-1771, edited by J.C. Beaglehole, Hakluyt and Cambridge University Press, Cambridge, 1955, p399.

${ }^{22}$ Alexandro Malaspina, 'A Political Examination of the English Colonies in the Pacific', in King. Robert J. King, The Secret History of the Convict Colony: Alexandro Malaspina's Report on the British Settlement of New South Wales, Allen \& Unwin, Sydney, 1990, pp144; 149.

${ }^{23}$ vol 3, p73.

${ }^{24}$ vol 3, p77.

${ }^{25}$ vol 3, p85.

${ }^{26}$ Donald C. Cutter, 'Malaspina and the Shrinking Spanish Lake', in Margarette Lincoln (ed), Science and Exploration in the Pacific: European Voyages to the Southern Oceans in the Eighteenth Century, Boydell \& Brewer, Woodbridge, 2001, p79.

${ }^{27}$ vol 1, plxxxii.

${ }^{28}$ vol 3, p78.

${ }^{29}$ vol 3, pp79-80

${ }^{30}$ Incidentally, Malaspina's closest connection in Spain is to Cadiz, in Andalusia. This is where he started his naval training in 1774, and from where the 1789 voyage departed.

${ }^{31}$ Alejandro Malaspina, Viaje político-científico alrededor del mundo por las corbetas Descubierta y Atrevida al mando de los capitanes de navio D. Alejandro Malaspina y Don José de Bustamante y Guerra desde 1789 á 1794, publicado con una introducción por Don Pedro de Novo y Colsón, teniente de navío, académico correspondiente de la real de la historia, segunda edición, Imprenta de la viuda e hijos de Abienzo, Madrid, 1885, p257.

${ }^{32}$ vol 3, pp84-5.

${ }^{33}$ Vincenzio Da Filicaja, Opere del senatore Vincenzio da Filicaja, Venice, 1804, vol 1, ppiii-xxx; 239.

${ }^{34}$ Frederic Regard, 'Introduction: Articulating Empire's Unstable Zones', in Frederic Regard (ed), British Narratives of Exploration: Case Studies of the Self and Other, Pickering \& Chatto, London, 2009, p9.

${ }^{35}$ Sandhya Patel, 'The (He)art of First Encounter at Tahiti: Samuel Wallis's Conflicts of Interest (1767)', in Frederic Regard (ed), British Narratives of Exploration: Case Studies of the Self and Other, Pickering \& Chatto, London, 2009, p71.

${ }^{36} \mathrm{My}$ use of 'self-understanding' is drawn from Frederick Cooper's, who defines it: 'It is a dispositional term that designates what might be called situated subjectivity: one's sense of who one is, of one's social location, and of how (given the first two) one is prepared to act'. Frederick Cooper, Colonialism in Question: Theory, Knowledge, History, University of California Press, Berkeley, c2005, p73. 